\title{
IMPACT OF NITROGEN NUTRITION ON PRODUCTIVITY AND NUTRIENT USE EFFICIENCY OF POTATO (Solanum tuberosum L.) IN AN INCEPTISOL OF WEST BENGAL, INDIA
}

\author{
H. Banerjee ${ }^{1}$, K. Ray ${ }^{2}$, S. Sarkar ${ }^{2}$, A. M. Puste*², M. Mozumder ${ }^{2}$ and L. Rana ${ }^{2}$ \\ Regional Research Station (CSZ), Bidhan Chandra Krishi Viswavidyalaya \\ Kakdwip, West Bengal, India
}

\begin{abstract}
The experiment was carried out at the District Seed Farm, Adisaptagram, Hooghly (West Bengal), India during two consecutive winter seasons of 2011-12 and 2012-13 to find out optimum N dose of potato cultivars for getting higher yield as well as to identity efficient potato cultivars regarding $\mathrm{N}$ use. Average yield of potato cultivars increased significantly with increase in $\mathrm{N}$ supply up to $225 \mathrm{~kg} \mathrm{~N} \mathrm{ha}^{-1}$, then tended to decrease slightly as nitrogen levels increased further. Tuber yield of cultivars Kufri Shailja and Kufri Jyoti was increased significantly with increase in nitrogen level up to $225 \mathrm{~kg} \mathrm{~N}^{-1}$ and further addition of $\mathrm{N}$ decreased yield. Yield of Kufri Himalini was increased with increase in $\mathrm{N}$ level up to $300 \mathrm{~kg} \mathrm{~N}^{-1}$ but the yield increment from $225 \mathrm{~kg} \mathrm{~N} \mathrm{ha}^{-1}$ to $300 \mathrm{~kg} \mathrm{~N} \mathrm{ha}^{-1}$ was not significant. Application of less $\mathrm{N}$ decreased average potato tuber yield by $5.3,18.7$ and $65.1 \%$ with 150,75 and $0 \mathrm{~kg} \mathrm{~N}^{-1}$ respectively, compared to $225 \mathrm{~kg} \mathrm{~N} \mathrm{ha}^{-1}$. Nitrogen use efficiency (NUE) decreased towards higher $\mathrm{N}$ levels for all cultivars. NUE of Kufri Himalini was higher at all $\mathrm{N}$ levels. The results revealed that irrespective of cultivar $225 \mathrm{~kg} \mathrm{~N}$ $\mathrm{ha}^{-1}$ was the optimum for getting higher tuber yield of potato and cultivar Kufri Himalini was the most efficient in case of $\mathrm{N}$ use.
\end{abstract}

Keywords: Potato cultivars, nitrogen recovery, NUE, productivity

\section{INTRODUCTION}

In India, more than $89 \%$ of the potato crop is raised in Gangetic plains during winter season (October to March). Although West Bengal accounts for one-third of the country's total potato production but potato growers for the last few years face some problems mainly due to lack of knowledge about new cultivar and appropriate

\footnotetext{
* Corresponding author email: ampuste bckv@yahoo.co.in

${ }^{1}$ Regional Research Station (CSZ), Bidhan Chandra Krishi Viswavidyalaya, Kakdwip, West Bengal, India

${ }^{2}$ Department of Agronomy, Bidhan Chandra Krishi Viswavidyalaya, Mohanpur, West Bengal, India
} 
doses of fertilizers. The best way to get rid of this situation would be introduction of improved potato cultivars having better yield potential and nutrient management practices. The new potato hybrids cv. 'Kufri Himalini' and 'Kufri Shailja' have primarily been developed with higher level of resistance to late blight and exhibited higher yield potential than existing popular variety of the region cv. 'Kufri Jyoti'.

Potato is nutrient exhaustive crop and responds well to the higher levels of fertilizer (Meena et al., 2013). Nitrogen determines the quantity and structure of potato yield, its chemical composition and tuber quality (Kolodziejczyk, 2014). Application of more $\mathrm{N}$ increased size and number of tubers ultimately enhancing total yield (Kumar et al., 2007). In addition, under- or over supply of $\mathrm{N}$ may affect total number of tubers. Excessive application of $\mathrm{N}$ leads to delay maturity, produce poor quality tuber and reduce tuber yield (Alva, 2004). However, nitrogen management is particularly relevant to the dry environment where nitrogen is inherently deficient and careful $\mathrm{N}$ supply is required to ensure high crop yield (Badr et al., 2012). In order to optimize crop production and minimize the risk of $\mathrm{N}$ leaching into groundwater, modern fertilizer practices involve optimization of $\mathrm{N}$. Potato cultivars differ in their growth behaviour, $\mathrm{N}$ requirement and yield potential. Therefore, this experiment was conducted to find out optimum $\mathrm{N}$ dose of potato cultivars for getting higher yield as well as to identify efficient potato cultivars regarding $\mathrm{N}$ use.

\section{MATERIALS AND METHODS}

A field experiment was conducted at the District Seed Farm $\left(23^{\circ} 26^{\prime} \mathrm{N}\right.$ latitude, $88^{\circ} 22^{\prime}$ E longitude and $12 \mathrm{~m}$ above mean sea level), Adisaptagram, Hooghly (West Bengal), India during two consecutive winter seasons (November-March) of 2011-12 and 2012-13 in an inceptisol (Great group Fluvaquents). The soil of the experimental site was loamy in texture (44, 30 and $26 \%$ of sand, silt and clay), with a slightly acidic (pH 6.34), EC of $0.25 \mathrm{dS} \mathrm{m}^{-1}, 0.60 \%$ organic carbon and the available $\mathrm{N}, \mathrm{P}$ and

$\mathrm{K}$ were $183.3,24.1$ and $614.03 \mathrm{~kg} \mathrm{ha}^{-1}$, respectively. The experiment was laid out in factorial randomized complete block design consisting of combinations of three potato cultivars (cv. Kufri Himalini, Kufri Shailja and Kufri Jyoti) and five nitrogen levels $\left(0,75,150,225\right.$ and $\left.300 \mathrm{~kg} \mathrm{~N} \mathrm{ha}^{-1}\right)$ with four replications. The unit plot size was $5 \mathrm{~m} \times 3 \mathrm{~m}$. Tubers weighing 30-40 $\mathrm{g}$ each were hand planted on $25^{\text {th }}$ and $27^{\text {th }}$ November during year 1 and year 2, respectively with a density of about 83,333 plants $\mathrm{ha}^{-1}(60 \mathrm{~cm} \times 20 \mathrm{~cm})$. Regarding the application of plant nutrients, half of nitrogen (urea) was broadcasted as basal and rest $1 / 2$ of nitrogen was top dressed at 30 days after planting (DAP) followed by earthing up. All treatments received $150 \mathrm{~kg} \mathrm{P}$ $\mathrm{ha}^{-1}$ (Single super phosphate) and $150 \mathrm{~kg} \mathrm{~K} \mathrm{ha}^{-1}$ (muriate of potash) as basal.

At harvest, haulm and tuber tissues were separated and dried at $70^{\circ} \mathrm{C}$ in a forced air oven for subsequent dry weight determination. Dried plant samples were then ground to pass through a $0.5 \mathrm{~mm}$ sieve and total $\mathrm{N}$ was determined by the micro- 
Kjeldahl method (Bremner and Mulvaney, 1982). For taking yield components viz., average tuber number per plant and average tuber weight per plant, plants from three linear metre from each plot were collected and total tuber yield was estimated from it. Lifting of potato tubers was done from each plot manually on $5^{\text {th }}$ and $7^{\text {th }}$ March during year 1 and year 2, respectively and tubers were graded into four categories namely, $0-25,26-50,51-75$ and $>75 \mathrm{~g}$ followed by counting and weighing of gradewise tubers. Nitrogen use efficiency (NUE) was calculated using the following equation (Badr et al., 2012):

$$
\mathrm{NUE}=\frac{\mathrm{Yt}-\mathrm{Yo}}{\mathrm{N}}
$$

Where,

$\mathrm{Yt}=$ total tuber yield under treatment $\left(\mathrm{kg} \mathrm{ha}^{-1}\right)$

Yo $=$ total tuber yield under control $\left(\mathrm{kg} \mathrm{ha}^{-1}\right)$ and

$\mathrm{N}=$ applied nitrogen $\left(\mathrm{kg} \mathrm{ha}^{-1}\right)$

Post-harvest $\mathrm{N}$ recovery was calculated using the following equation (Badr et al., 2012):

$$
\mathrm{N} \text { recovery }=\frac{\mathrm{Nt}-\mathrm{No}}{\mathrm{N}} \times 100
$$

Where,

$\mathrm{Nt}=$ total $\mathrm{N}$ uptake by crop (haulm + tuber) under treatment $\left(\mathrm{kg} \mathrm{ha}^{-1}\right)$

$\mathrm{No}=$ total $\mathrm{N}$ uptake under control $\left(\mathrm{kg} \mathrm{ha}^{-1}\right)$ and

$\mathrm{N}=$ applied nitrogen $\left(\mathrm{kg} \mathrm{ha}^{-1}\right)$.

Data were subjected to analysis of variance as factorial $3 \times 5$ on randomized complete block design by using Windows-based SPSS software (ver 10.0, SPSS Inc 1996). The variance over years was estimated homogeneously by performing Bartlett's chi-square test and pooled analyses of observations are presented to draw logical conclusions. The Microsoft Excel software (version 2007, Microsoft Inc., WA, USA) was used to draw figures.

\section{RESULTS AND DISCUSSION}

\section{Total tuber yield and yield components of potato}

Average tuber yield of potato increased significantly with increase in $\mathrm{N}$ levels up to $225 \mathrm{~kg} \mathrm{~N}^{-1}$, then decreased slightly as nitrogen levels increased further (Table 1). Tuber yield of Kufri Shailja and Kufri Jyoti increased up to $225 \mathrm{~kg} \mathrm{~N} \mathrm{ha}^{-1}$, then declined at higher $\mathrm{N}$ levels. On the contrary, tuber yield of Kufri Himalini increased significantly with increase in $\mathrm{N}$ levels up to $225 \mathrm{~kg} \mathrm{~N}^{-1}$; further addition of $\mathrm{N}$ (up to $300 \mathrm{~kg} \mathrm{~N} \mathrm{ha}^{-1}$ ) increased yield but the increment from $225 \mathrm{~kg} \mathrm{~N} \mathrm{ha}^{-1}$ to $300 \mathrm{~kg} \mathrm{~N} \mathrm{ha}{ }^{-1}$ was not significant. Due to application of less amount of nitrogen, 
average potato yield decreased by $5.3,18.7$ and $65.1 \%$ with 150,75 and $0 \mathrm{~kg} \mathrm{~N}^{-1}$, respectively compared to $225 \mathrm{~kg} \mathrm{~N} \mathrm{ha}^{-1}$. Average tuber number per plant and average tuber weight per plant increased with the increase in $\mathrm{N}$ levels up to $225 \mathrm{~kg} \mathrm{~N}^{-1}$ and then decreased at the highest $\mathrm{N}$ level $\left(300 \mathrm{~kg} \mathrm{~N} \mathrm{ha}^{-1}\right)$. Tuber number per plant of Kufri Himalini was responsive up to $300 \mathrm{~kg} \mathrm{~N} \mathrm{ha}^{-1}$ but that of Kufri Shailja and Kufri Jyoti were responsive up to $225 \mathrm{~kg} \mathrm{~N} \mathrm{ha}^{-1}$. On the other hand, tuber weight per plant of Kufri Himalini and Kufri Jyoti was responsive up to $300 \mathrm{~kg} \mathrm{~N}^{-1}$, while that of Kufri Shailja was responsive up to $225 \mathrm{~kg} \mathrm{~N} \mathrm{ha}^{-1}$. Tuber number per plant was more stable to $\mathrm{N}$ deficit than tuber weight per plant. So, tuber yield in different treatments depend mainly on tuber weight per plant. More tuber yield with increasing fertilizer dose was also reported by Sarkar et al. (2011). The higher N increase leaf area which in turn intercepted more solar radiation and produced more photo-assimilate and stored in tubers (Baishya et al., 2013).

The correlation between tuber yield and tuber number per plant was moderate $\left(\mathrm{R}^{2}=0.73\right)$, indicating that the tuber number per plant contributed less in tuber yield (Figure 1a). On the other hand, the correlation between tuber yield and tuber weight per plant was very strong $\left(\mathrm{R}^{2}=0.86\right)$ indicated that the increase in tuber yield in different treatments was attributed mainly to the increase in tuber weight per plant (Figure 1b). Badr et al. (2012) also stated that tuber number and tuber weight per plant jointly increased tuber yield. This findings implies that increasing $\mathrm{N}$ level under irrigated situation will be effective up to a certain level, beyond that an adverse effect of excessive $\mathrm{N}$ on yields is obvious.

\section{Grade-wise tuber yield of potato}

The cultivar Kufri Himalini produced significantly higher yield of small grade (29.46\% over Kufri Shailja and $56.85 \%$ over Kufri Jyoti) and large grade (39.05\% over Kufri Shailja and $56.41 \%$ over Kufri Jyoti) tubers (Table 2). Diengdoh et al. (2012) also found better growth of the above ground parts lead to more photosynthetic formation and their translocation and accumulation in the sink (tuber) resulting in higher yield of cv. Kufri Himalini. On the contrary, Kufri Shailja gave higher yield of semi-medium grade $(34.18 \%$ over Kufri Himalini and $51.69 \%$ over Kufri Jyoti, respectively) as well as medium grade tubers $(23.17 \%$ over Kufri Himalini and $38.86 \%$ over Kufri Jyoti). Grade-wise tuber yield was significantly influenced by $\mathrm{N}$ levels, except small grade tubers (Table 2). Yield of semi-medium, medium, and large grade tubers was increased with increase in $\mathrm{N}$ level. Nitrogen at $225 \mathrm{~kg} \mathrm{~N} \mathrm{ha}{ }^{-1}$ produced maximum yield of semi-medium grade tubers, while medium and large grade tubers production was maximum with $300 \mathrm{~kg} \mathrm{~N} \mathrm{ha}^{-1}$. Mean yield of bigger size tubers (large grade) was significantly higher with $300 \mathrm{~kg} \mathrm{~N}^{-1}$. Interaction effect was also significant. Bigger size (large grade) tuber production was increased significantly with increase in $\mathrm{N}$ level up to $300 \mathrm{~kg} \mathrm{~N} \mathrm{ha}^{-1}$ for cv. Kufri Himalini and Kufri Shailja, and $225 \mathrm{~kg} \mathrm{~N}^{-1}$ for cv. Kufri Jyoti. Both Kufri Himalini and Kufri Shailja produced significantly higher yield of large grade tubers 
with $300 \mathrm{~kg} \mathrm{~N} \mathrm{ha}^{-1}$ (87.89 and $65.89 \%$ over control respectively) while Kufri Jyoti gave significantly higher large grade tuber yield with $225 \mathrm{~kg} \mathrm{~N} \mathrm{ha}^{-1}(61.92 \%$ over control). Zaman et al. (2011) also had a similar opinion that inorganic source of nutrient was in favour of producing large and very large sized tubers, regardless of cultivar.

\section{Nitrogen use efficiency, total $\mathbf{N}$ uptake and $\mathbf{N}$ recovery by potato cultivars}

Nitrogen use efficiency (NUE) was influenced greatly by the amount of $\mathrm{N}$, the most efficient treatments being those which received less amount of $\mathrm{N}$ indicating that NUE was inversely proportional to the amount of $\mathrm{N}$ applied (Table 3). The higher

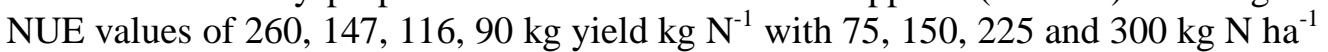
, respectively were recorded in cv. Kufri Himalini, indicated that Kufri Himalini was the most efficient in case of NUE. Similar trend was observed by Cabello et al. (2009) who found that plants grown under limiting nitrogen supply extracted more $\mathrm{N}$ from the soil.

In terms of total $\mathrm{N}$ uptake by the crop (Table 3), there was an important difference between $\mathrm{N}_{75}$ and $\mathrm{N}_{300}$ at full irrigation supply (230.7 versus $363 \mathrm{~kg} \mathrm{~N} \mathrm{ha}^{-1}$ ). Such a large uptake was due to higher $\mathrm{N}$ contents in the haulms and tubers as well as higher dry matter. However, $\mathrm{N}$ uptake decreased with increase in $\mathrm{N}$ level indicating luxury consumption of $\mathrm{N}$. Although this luxury consumption of $\mathrm{N}$ no longer contributes to physiological processes but may be accumulated in storage organs (Marschner, 1995). As a proportion of the $\mathrm{N}$ recovery, the lowest $\mathrm{N}$ level $(75 \mathrm{~kg} \mathrm{~N}$ $\mathrm{ha}^{-1}$ ) gave the most satisfactory values of 173, 272 and 124\% for cv. Kufri Himalini, Kufri Shailja and Kufri Jyoti, respectively (Table 3). This higher utilization may be attributed to extraction of more nitrogen under N-stress conditions (Badr et al., 2012).

\section{CONCLUSION}

The results showed that potato yield and its components were significantly affected by $\mathrm{N}$ level. Tuber weight per plant was more sensitive to nitrogen deficit than tuber number per plant, and the decrease in tuber yield in $\mathrm{N}$ deficit treatments was mainly due to a decrease in tuber weigh per plant. Tuber yield at full irrigation supply increased with increase in $\mathrm{N}$ level. The NUE decreased with increase in $\mathrm{N}$ level for all the cultivars. The results revealed that irrespective of cultivar $225 \mathrm{~kg} \mathrm{~N}$ $\mathrm{ha}^{-1}$ was the optimum for getting higher tuber yield of potato and cultivar Kufri Himalini was the most efficient in case of $\mathrm{N}$ use.

\section{REFERENCES}

Alva A. 2004. Potato nitrogen management. Journal of Vegetable Crop Production, 10: 97130

Badr, M. A., El-Tohamy, W. A. and Zaghloul, A. M. 2012. Yield and water use efficiency of potato grown under different irrigation and nitrogen levels in an arid region. Agricultural Water Management, 110: 9-15 
Baishya, L. K., Kumar, M., Ghosh, M. and Ghosh, D. C. 2013. Effect of integrated nutrient management on growth, productivity and economics of rainfed potato in Meghalaya hills. International Journal of Agriculture, Environment and Biotechnology, 6: 69-77

Bremner, J. M. and Mulvaney, C. S. 1982. Nitrogen-total. In: Page A.L. et al. (Eds.), Methods of Soil Analysis. Part II. Agronomy Monograph, $2^{\text {nd }}$ ed. ASA and SSSA, Madison, WI, pp. 595-624

Cabello, M. J., Castellanos, M. T., Romojaro, F., Martinez-Madrid, C. and Ribas, F. 2009. Yield and quality of melon grown under different irrigation and nitrogen rates. Agricultural Water Management, 96: 866-874

Diengdoh, L. C., Rai R., Srivastava, A. K. and Bag, T. K. 2012. Optimizing crop geometry for potato mini-tuber multiplication in net-house. International Journal of Agriculture, Environment and Biotechnology, 5: 113-115

Kolodziejczyk, M. 2014. Effect of nitrogen fertilization and microbial populations on potato yielding. Plant Soil and Environment, 60: 379-386

Kumar, P., Pandey, S. K., Singh, B. P., Singh, S. V. and Kumar, D. 2007. Effect of nitrogen rate on growth, yield, economics and crisps quality of Indian potato processing cultivars. Potato Research, 50: 143-155

Marschner, H. 1995. Mineral Nutrition of Higher Plants. Academic Press Inc., San Diego, CA

Meena, B. P., Kumar, A., Meena, S. R., Dhar, S., Rana, D. S. and Rana, K. S. 2013. Effect of sources and nutrients on growth and yield behaviour of pop corn (Zea mays) and potato (Solanum tuberosum) sequence. Indian Journal of Agronomy, 58: 474-479

Sarkar, A., Sarkar, S., Zaman, A. and Devi, W. P. 2011. Productivity and profitability of different cultivars of potato (Solanum tuberosum) as affected by organic and inorganic sources of nutrients. Indian Journal of Agronomy, 56: 159-163

Zaman, A., Sarkar, A., Sarkar, S. and Devi, W. P. 2011. Effect of organic and inorganic sources of nutrients on productivity, specific gravity and processing quality of potato (Solanum tuberosum). Indian Journal of Agricultural Sciences, 81: 1137-1142 
Table 1. Total tuber yield, tuber number and tuber weight per plant of different potato cultivars grown under different nitrogen levels (data pooled over 2 years)

\begin{tabular}{|c|c|c|c|c|c|c|}
\hline \multirow[t]{2}{*}{ Cultivars } & \multicolumn{6}{|c|}{ Nitrogen levels $\left(\mathrm{kg} \mathrm{ha}^{-1}\right)$} \\
\hline & $\mathbf{N}_{0}$ & $\mathbf{N}_{75}$ & $\mathbf{N}_{150}$ & $\mathbf{N}_{225}$ & $\mathbf{N}_{300}$ & Mean \\
\hline \multicolumn{7}{|c|}{ Total tuber yield $\left(\mathrm{t} \mathrm{ha}^{-1}\right)$} \\
\hline Kufri Himalini & 12.38 & 31.88 & 34.40 & 38.40 & 39.50 & 31.32 \\
\hline Kufri Shailja & 12.06 & 31.26 & 32.72 & 32.74 & 24.06 & 26.57 \\
\hline Kufri Jyoti & 11.44 & 20.34 & 30.18 & 31.58 & 26.91 & 24.09 \\
\hline Mean & 11.96 & 27.83 & 32.43 & 34.24 & 30.16 & \\
\hline \multicolumn{7}{|c|}{ Tuber number plant ${ }^{-1}$} \\
\hline Kufri Himalini & 3.00 & 6.25 & 7.50 & 8.00 & 8.50 & 6.45 \\
\hline Kufri Shailja & 3.75 & 8.50 & 8.75 & 9.50 & 6.75 & 7.45 \\
\hline Kufri Jyoti & 3.75 & 3.50 & 6.00 & 7.75 & 7.25 & 5.65 \\
\hline Mean & 3.50 & 6.08 & 7.42 & 8.08 & 7.50 & \\
\hline \multicolumn{7}{|c|}{ Tuber weight (g plant ${ }^{-1}$ ) } \\
\hline Kufri Himalini & 30.99 & 117.66 & 144.23 & 149.29 & 155.28 & 117.49 \\
\hline Kufri Shailja & 43.09 & 139.02 & 153.01 & 163.01 & 108.14 & 121.25 \\
\hline Kufri Jyoti & 51.80 & 48.21 & 113.85 & 126.04 & 131.02 & 94.18 \\
\hline Mean & 41.96 & 101.63 & 137.03 & 142.78 & 131.48 & \\
\hline \multicolumn{7}{|l|}{ LSD $(\mathrm{P}<0.05)$} \\
\hline Factor & $\begin{array}{l}\text { Total } \\
\text { yield }\end{array}$ & $\begin{array}{c}\text { Tuber } \\
\text { number }\end{array}$ & $\begin{array}{c}\text { Tuber } \\
\text { weight }\end{array}$ & & & \\
\hline Cultivar & 3.64 & NS & NS & & & \\
\hline Nitrogen & 4.70 & 2.01 & 38.08 & & & \\
\hline Interaction & NS & NS & NS & & & \\
\hline
\end{tabular}

NS, Non-significant 
Table 2. Grade-wise tuber yield of potato as influenced by the cultivars and levels of $\mathrm{N}$ (data pooled over 2 years)

\begin{tabular}{|c|c|c|c|c|c|c|}
\hline \multirow[t]{2}{*}{ Cultivars } & \multicolumn{6}{|c|}{ Nitrogen levels $\left(\mathrm{kg} \mathrm{ha}^{-1}\right)$} \\
\hline & $\mathbf{N}_{\mathbf{0}}$ & $\mathbf{N}_{75}$ & $\mathbf{N}_{150}$ & $\mathbf{N}_{225}$ & $\mathbf{N}_{300}$ & Mean \\
\hline \multicolumn{7}{|c|}{$0-25 \mathrm{~g}$ (small) tuber yield $\left(\mathrm{t} \mathrm{ha}^{-1}\right)$} \\
\hline Kufri Himalini & 3.27 & 1.89 & 2.47 & 2.37 & 2.06 & 2.41 \\
\hline Kufri Shailja & 1.71 & 1.61 & 1.04 & 2.32 & 1.82 & 1.70 \\
\hline Kufri Jyoti & 0.96 & 1.27 & 1.00 & 1.13 & 0.84 & 1.04 \\
\hline Mean & 1.98 & 1.59 & 1.50 & 1.94 & 1.57 & \\
\hline \multicolumn{7}{|c|}{ 26-50g (semi-medium) tuber yield $\left(\mathrm{t} \mathrm{ha}^{-1}\right)$} \\
\hline Kufri Himalini & 3.00 & 2.88 & 2.99 & 3.85 & 2.86 & 3.12 \\
\hline Kufri Shailja & 2.19 & 4.49 & 3.85 & 7.84 & 5.33 & 4.74 \\
\hline Kufri Jyoti & 1.63 & 1.47 & 3.18 & 2.19 & 2.99 & 2.29 \\
\hline Mean & 2.27 & 2.95 & 3.34 & 4.63 & 3.72 & \\
\hline \multicolumn{7}{|c|}{ 51-75g (medium) tuber yield $\left(\mathrm{t} \mathrm{ha}^{-1}\right)$} \\
\hline Kufri Himalini & 2.90 & 3.76 & 4.83 & 4.03 & 6.04 & 4.31 \\
\hline Kufri Shailja & 2.92 & 7.25 & 6.30 & 5.91 & 5.70 & 5.61 \\
\hline Kufri Jyoti & 1.78 & 3.48 & 3.72 & 3.52 & 4.64 & 3.43 \\
\hline Mean & 2.53 & 4.83 & 4.95 & 4.48 & 5.46 & \\
\hline \multicolumn{7}{|c|}{$>75 \mathrm{~g}$ (large) tuber yield $\left(\mathrm{t} \mathrm{ha}^{-1}\right)$} \\
\hline Kufri Himalini & 1.20 & 7.48 & 13.02 & 11.75 & 16.09 & 9.91 \\
\hline Kufri Shailja & 2.06 & 4.67 & 8.30 & 5.66 & 9.50 & 6.04 \\
\hline Kufri Jyoti & 2.14 & 3.31 & 5.06 & 5.62 & 5.50 & 4.32 \\
\hline Mean & 1.80 & 5.15 & 8.79 & 7.68 & 10.36 & \\
\hline \multicolumn{7}{|l|}{ LSD (P<0.05) } \\
\hline Factor & $0-25 \mathrm{~g}$ & $26-50 \mathrm{~g}$ & $51-75 \mathrm{~g}$ & $>75 \mathrm{~g}$ & & \\
\hline Cultivar & 0.40 & 0.90 & 0.86 & 1.24 & & \\
\hline Nitrogen & NS & 1.16 & 1.10 & 1.60 & & \\
\hline Interaction & NS & 2.01 & NS & 2.77 & & \\
\hline
\end{tabular}

NS, Non-significant 
Table 3. Nitrogen use efficiency (NUE), total $\mathrm{N}$ uptake (haulm + tuber) and $\mathrm{N}$ recovery by potato cultivars grown under different nitrogen levels (data pooled over two years)

\begin{tabular}{|c|c|c|c|c|}
\hline Cultivar & Nitrogen level & $\begin{array}{l}\text { NUE (kg yield } \\
\left.\quad \operatorname{kg~N~N}^{-1}\right)\end{array}$ & $\begin{array}{l}\text { Total N uptake } \\
\quad\left(\mathrm{kg} \mathrm{ha}^{-1}\right)\end{array}$ & $\begin{array}{c}\mathrm{N} \text { recovery } \\
(\%)\end{array}$ \\
\hline \multirow{5}{*}{$\begin{array}{l}\text { Kufri } \\
\text { Himalini }\end{array}$} & $\mathrm{N}_{0}$ & - & 72 & - \\
\hline & $\mathrm{N}_{75}$ & 260 & 202 & 173 \\
\hline & $\mathrm{N}_{150}$ & 147 & 307 & 157 \\
\hline & $\mathrm{N}_{225}$ & 116 & 330 & 115 \\
\hline & $\mathrm{N}_{300}$ & 90 & 360 & 96 \\
\hline \multirow[t]{5}{*}{ Kufri Shailja } & $\mathrm{N}_{0}$ & - & 117 & - \\
\hline & $\mathrm{N}_{75}$ & 256 & 321 & 272 \\
\hline & $\mathrm{N}_{150}$ & 138 & 413 & 197 \\
\hline & $\mathrm{N}_{225}$ & 92 & 454 & 150 \\
\hline & $\mathrm{N}_{300}$ & 40 & 399 & 94 \\
\hline \multirow[t]{5}{*}{ Kufri Jyoti } & $\mathrm{N}_{0}$ & - & 76 & - \\
\hline & $\mathrm{N}_{75}$ & 119 & 169 & 124 \\
\hline & $\mathrm{N}_{150}$ & 125 & 246 & 113 \\
\hline & $\mathrm{N}_{225}$ & 90 & 327 & 112 \\
\hline & $\mathrm{N}_{300}$ & 52 & 330 & 85 \\
\hline \multicolumn{5}{|l|}{ LSD $(\mathrm{P}<0.05)$} \\
\hline Factor & & NUE & Total $\mathrm{N}$ uptake & $\mathrm{N}$ recovery \\
\hline Cultivar & & - & NS & - \\
\hline Nitrogen & & - & 44.27 & - \\
\hline Interaction & & - & NS & - \\
\hline
\end{tabular}

NS, Non-significant 


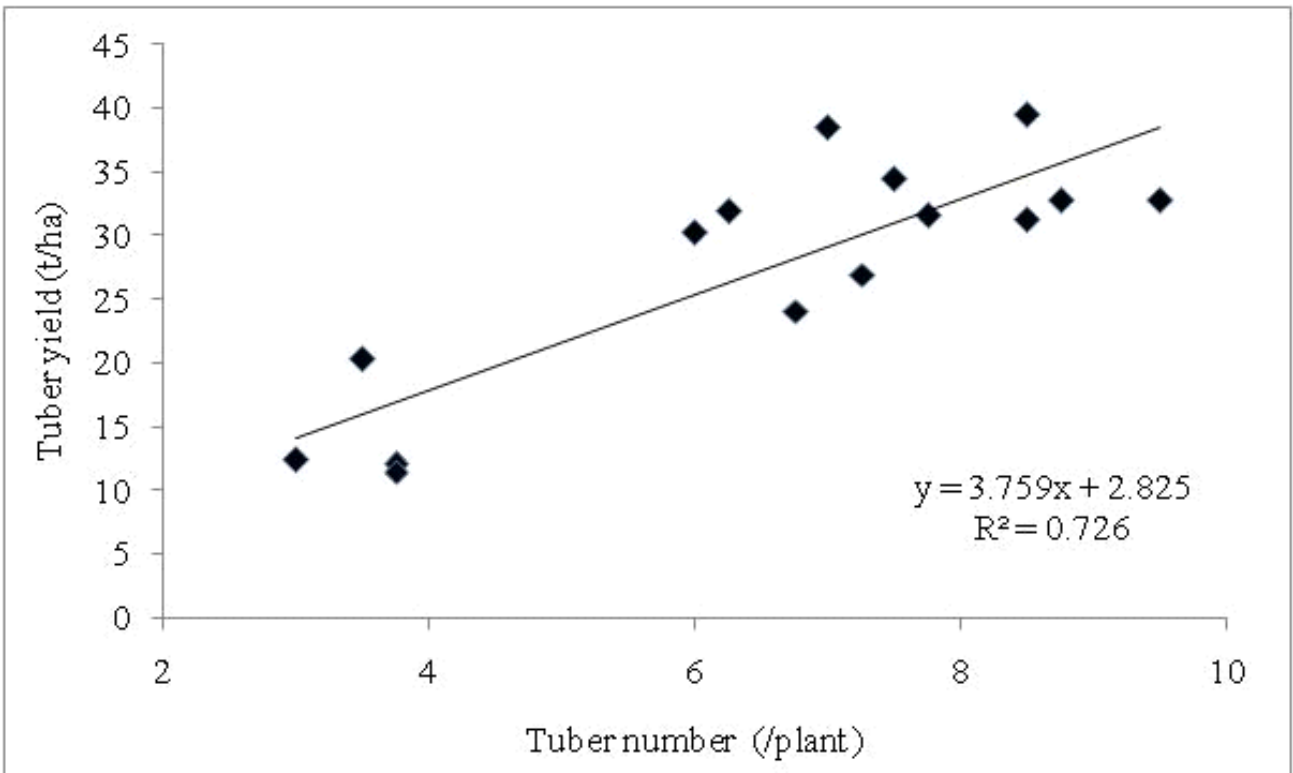

[a]

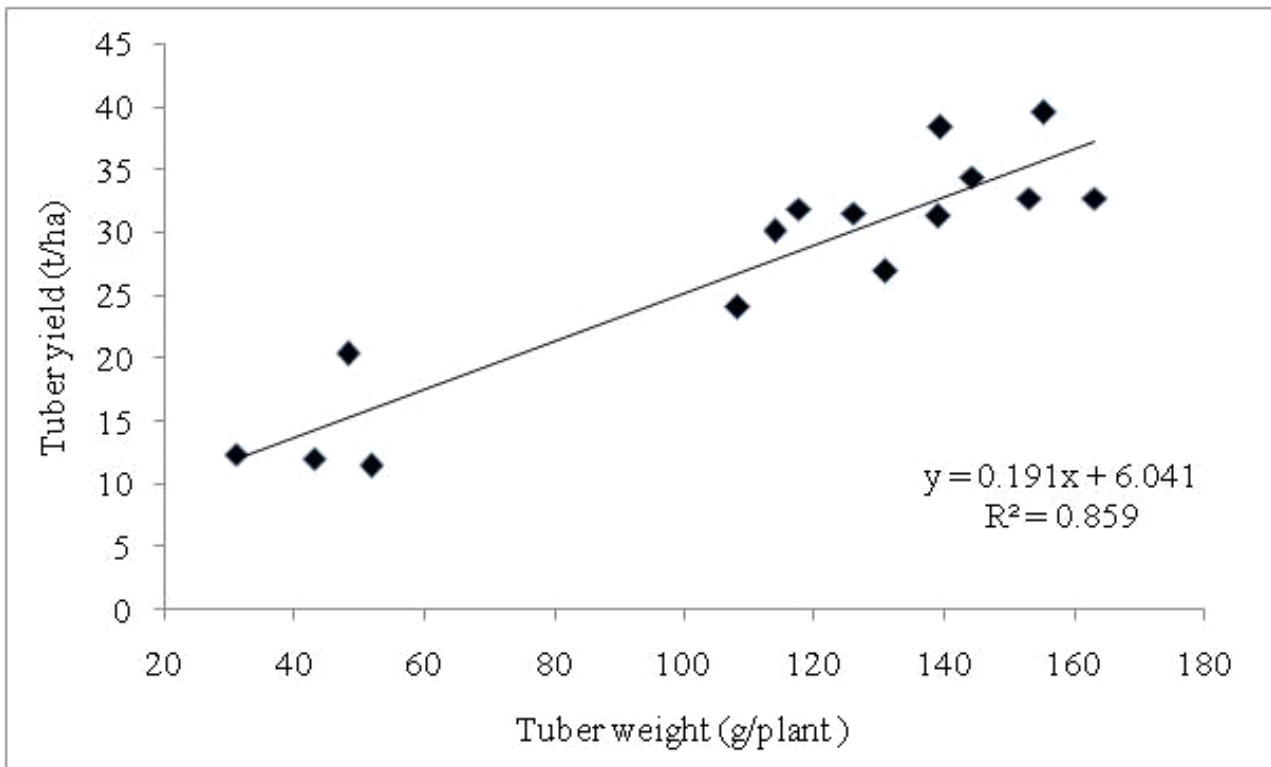

[b]

Figure 1. Association of total tuber yield with [a] tuber number per plant and [b] tuber weight per plant of potato 